\title{
James Ross (I837-1892) and his forgotten neurology textbook of 1881
}

\author{
MJ Eadie \\ Emeritus Professor of Clinical Neurology and Neuropharmacology, Central Clinical School (University of Queensland), Royal Brisbane and \\ Women's Hospital, Brisbane, Australia
}

\begin{abstract}
James Ross ( $1837-1892$ ) was an Aberdeen medical graduate who, after 13 years in rural general practice, mainly in Lancashire, became a pathologist and then physician to the Manchester Royal Infirmary and professor of medicine at Owens College, Manchester. In mid-career he developed a major interest in clinical neurology and became, apart from Byrom Bramwell in Edinburgh, the only contemporary British physician outside London who had widely recognised neurological expertise. Ross made several notable original contributions to neurological knowledge, particularly in relation to aphasia and peripheral neuritis. He wrote the entire contents of the two editions of the massive two-volume A Treatise on the Diseases of the Nervous System (I88I and 1883), which was very favourably reviewed and commercially successful but which, like its author who died at the height of his powers, was soon forgotten once William Gowers' A Manual of Diseases of the Nervous System became available in the late 1880s.
\end{abstract}

KEYWORDS Early neurological textbooks, William Gowers, Manchester, James Ross

Correspondence to MJ Eadie, Central Clinical School (University of Queensland), Royal Brisbane and Women's Hospital, Brisbane, Australia, 4027

tel. +6I $7383 I I 704$

e-mail m.eadie@uq.edu.au

DECLARATION OF INTERESTS No conflict of interests declared.

\section{INTRODUCTION}

Clinical neurology emerged as an area of specialised medical activity in the latter half of the nineteenth century. At that time several medium-sized, single-authored texts on nervous system disease were published, beginning with Moritz Romberg's A Manual of the Nervous Diseases of Man in 1840 and 185I, translated into English by Edward Sieveking in 1853.' This was followed by the works of Moritz Rosenthal in 1870 (with an English translation by Leopold Putzel in $1879^{2}$ ) and those of William Hammond in $187 I^{3}$ and Samuel Wilks in $1878 .^{4}$ There were also multiple-authored accounts of nervous system disease in contemporary medical encyclopaedias such as those in Russell Reynolds' System of Medicine ${ }^{5}$ and Hugo von Ziemssen's Cyclopaedia of the Practice of Medicine (English translation 1877). ${ }^{6}$ An English-language translation of JeanMartin Charcot's lectures appeared in three volumes in $1877,188 \mathrm{I}$ and 1889 respectively.

In addition, two large, single-authored, major comprehensive accounts of disease of the nervous system were published in the 1880s, each in two substantial volumes. The first of these accounts, written by James Ross of Manchester, appeared in 1881, with a second edition two years later; the two volumes of the other, written by William Gowers of London, were published in 1886 and 1888 respectively, with second editions in 1892 and 1893 and a third edition of volume one in 1899. The two volumes of Gowers'A Manual of Diseases of the Nervous System ${ }^{8}$ have been widely regarded as the 'Bible of neurology', and their author accepted as one of the greatest figures in the history of neurological knowledge. By contrast, Ross and his A Treatise on the Diseases of the Nervous System ${ }^{9}$ are now almost forgotten. This paper aims to establish the reasons for this.

\section{JAMES ROSS'S CAREER}

Several accounts of James Ross's life are available. ${ }^{10-14} \mathrm{He}$ was born at Kingussie, Inverness-shire, on II January 1837, the third son of John Ross, farmer, and his wife Christina, née MacPherson. He was educated at the Laggan Parish School, a few miles from his home, and then at the Normal College for Teachers, Edinburgh, but, realising that he was not temperamentally suited to school teaching, he turned to the study of medicine, graduating MB, CM from Aberdeen in 1863, and becoming $M D$ in 1865.

Following his graduation Ross went on two voyages to Greenland in whaling ships before entering general practice at Knottingley, Yorkshire, where he worked from 1863 to 1865. He then spent a short time at Burnley, before settling at Waterfoot in Rossendale, Lancashire, where he remained until 1876. During his time in general practice Ross carried out animal experiments, recording that he had studied the microscopic appearance of the mesentery after inducing inflammation by injecting a few drops of ammonia into a frog's leg. ${ }^{15}$ Ross transferred his medical activities to Manchester in 1876 to work as a pathologist to the Manchester Royal Infirmary. In that year he took the MRCP (London), becoming FRCP in 1882. His alma mater subsequently conferred on him its LL.D in 1883. In October 1878 Ross was appointed assistant 
physician to the Manchester Royal Infirmary, becoming full physician there in 1888, a year after he had been elected Joint Professor of Medicine at Owens College, Manchester. Ross became a very popular and busy consultant who, with the exception of Byrom Bramwell in Edinburgh, was the only physician in Great Britain outside London to have a major neurological interest and reputation. In late 1890 he became ill with what proved to be cancer of the stomach, from which he died on 25 February 1892, aged 55.

Ross had married Mary Bolton in 1869. At the time of the I88I British census, the Ross household at 335 Oxford Street, Chorlton on Medlock, Lancashire, comprised Ross, his wife Mary, two daughters and a son, four domestic servants, and his older brother John. The latter was presumably visiting at the time as he spent most of his adult life in Australia, where he became a notable figure for his involvement in various aspects of radical social activity. ${ }^{16}$ James Ross himself was described as being of average height and build, with a close-cropped beard (Figure I). ${ }^{12}$ William Brockbank wrote that he was an 'unostentatious, lovable man with an endearing absent-mindedness caused by his preoccupation with philosophical problems'. ${ }^{14}$ Ross's Lancet obituary described how, in general practice, he had ridden several miles to see a patient in a cottage and then made his way back to his own home on foot, his mind focused on lofty matters, forgetting his horse left behind at the cottage. ${ }^{10}$

\section{JAMES ROSS'S PUBLISHED WORKS}

From early in his time in general practice, Ross published in the medical press. Prior to his move to Manchester in 1876, his writings spanned a diverse range of topics, none of them specifically neurological. His early publications reflect a broad range of biological interests, a philosophical bent, a penchant for logical reasoning and, at times, a willingness to engage in written controversy concerning matters about which he appeared to feel strongly. He dealt with issues such as the role of micro-circulation in inflammation involving mucous membranes ${ }^{17}$ and counterirritation. ${ }^{18} \mathrm{He}$ published logic-based criticisms of how George Rolleston had interpreted the so-called 'law of parsimony' in nature, ${ }^{19}$ and of some of the facts and interpretations on which Henry Howorth had based his objection to Darwin's concept of natural selection. ${ }^{20}$ After Ross had criticised what he considered was Bell Pettigrew's interpretation of Thomas Huxley's ideas on the nature of protoplasm, ${ }^{21}$ he went to the length of a 125-page monograph to examine Hutchinson Stirling's criticism of Huxley's views. ${ }^{22}$

In 1872 Ross wrote a paper which within the year he had expanded into a monograph on what he termed the 'graft theory of disease'. ${ }^{23}$ Written at a time when the role of bacteria in causing infectious disease was still controversial, Ross's monograph drew on the known

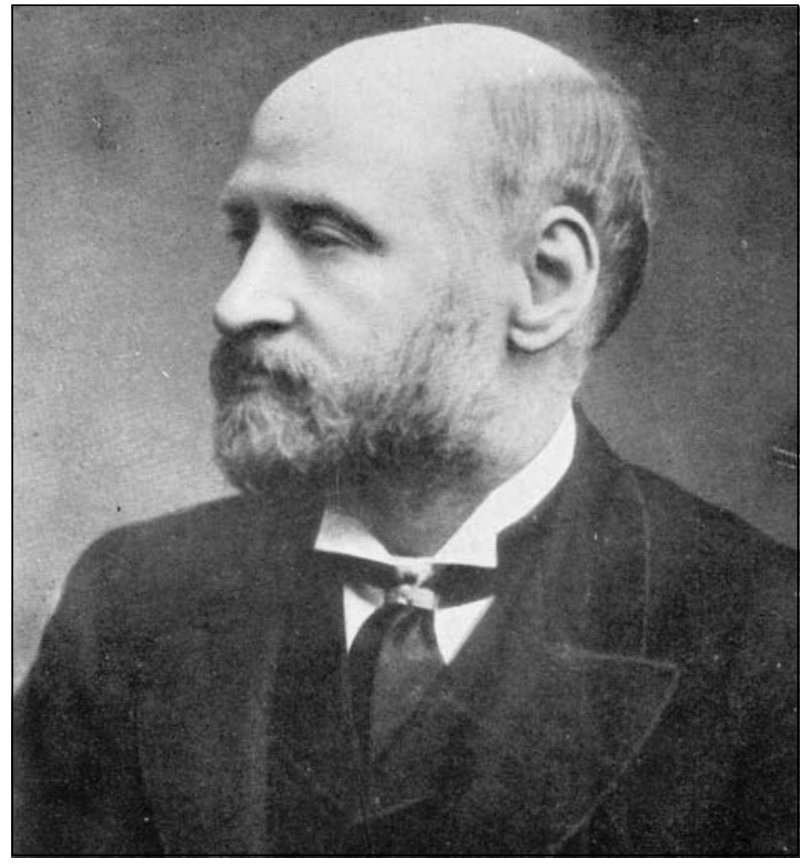

FIGURE I James Ross (1837-I892), taken from Geoffrey Jefferson's Selected Papers. ${ }^{13}$

phenomenon that a branch of one tree from a particular species could be grafted successfully onto a tree of a closely related species to produce a hybrid of the two. In like manner, he hypothesised that particles of contagious matter, which although they resembled bacteria, were not 'independent beings', might hybridise with and perhaps damage body cells in the process of forming new 'modified units of the individual from which they have become detached'. ${ }^{23}$ The new modified units presumably then hybridised with more body cells to perpetuate the process and spread the contagion. The idea, incorrect in denying the role of bacteria in infective disease, reflected Ross's enthusiasm for Darwinian and Spencerian ideas and reveals his capacity to conceive and develop original ideas.

During his general practice years Ross also wrote on the action of alcohol ${ }^{15}$ and on the mechanism of action of mercury in treating syphilis. ${ }^{24}$ In the latter paper, and in a paper on comparative pharmacology and therapeutics, ${ }^{25}$ he tried to develop a physico-chemical hypothesis about the nature of drug action. This hypothesis regarded molecular size and mobility as significant factors in drug action, and used the concept of 'like gathering to like' to explain the affinities of drugs for particular tissues, a concept that could be seen as a precursor to the later receptor theory of drug action.

From a man engaged in a busy solo general practice in rural Lancashire this was a very substantial output of published works, some containing quite original ideas. It marked Ross as a person of unusual mental powers, but also someone prone to enter into controversy. 
During the second half of the 1870s, Ross's output of publications decreased substantially, coinciding with his departure from general practice, his time in pathology and his preparation for a second career as a consultant physician with major neurological interests. It seems likely that over these apparently inactive years he devoted some of his energies to acquiring the knowledge and amassing the material for his neurological writings which began to appear in some profusion from 1880 onwards.

Apart from the two editions of Ross's A Treatise on the Diseases of the Nervous System ${ }^{9}$ (Figure 2) and the Handbook of the Diseases of the Nervous System, ${ }^{26}$ which was essentially a condensed version of the Treatise designed for the American market, Ross published a number of neurological papers and monographs. In 1880 he described his work on the arterial supply of the spinal $\operatorname{cord}^{27}$ and two cases of intracranial tumour in which the main interest lay in the localisation of function in the human cerebral cortex, ${ }^{28}$ a matter to which considerable attention was being paid following the publications of John Hughlings Jackson ${ }^{29}$ and of Gustav Fritsch and Eduard Hitzig ${ }^{30}$ in 1870 and the subsequent investigations of David Ferrier. ${ }^{31}$ Later, in a case which at autopsy had tubercular tumours at multiple sites in the central nervous system, Ross tried to reconcile the clinical features with the sites of the lesions. ${ }^{32}$

In I88I Ross described the progressive recovery of speech in amnesic aphasia following a recent head injury. ${ }^{33}$ He continued to collect further instances of aphasia, and these in 1887 provided the basis for the first English-language monograph on that topic, ${ }^{34}$ although English authors such as Hughlings Jackson ${ }^{35}$ and William Broadbent ${ }^{36}$ had already made substantial contributions to knowledge of the subject. Ross's interpretation of the anatomical basis of such speech defects did not envisage particular aspects of speech function being as rigidly localised into cortical centres and interconnected pathways as Broadbent had earlier suggested.

Ross described a case of probable arteriopathic pseudobulbar palsy under the designation 'labio-glossopharyngeal paralysis of cerebral origin' in $1882,{ }^{37}$ and in the following year his autopsy study of a case of pseudohypertrophic paralysis persuaded him that this was a primary disorder of muscle rather than a disorder of the nervous system which affected muscle. ${ }^{38}$ In 1882 there was also a long two-part paper on the spasmodic (i.e. spastic) paralyses of infancy. ${ }^{39}$ Two years later Ross published a small monograph on the diagnosis of various forms of paralysis of the muscles of external relation ${ }^{40}$ and in 1886 he reported an instance of "locomotor apraxia' with laryngeal crises and another, complicated by external ophthalmo-plegia, in which, at autopsy, there was primary sclerosis of Goll's columns (presumably tabes dorsalis). ${ }^{41}$

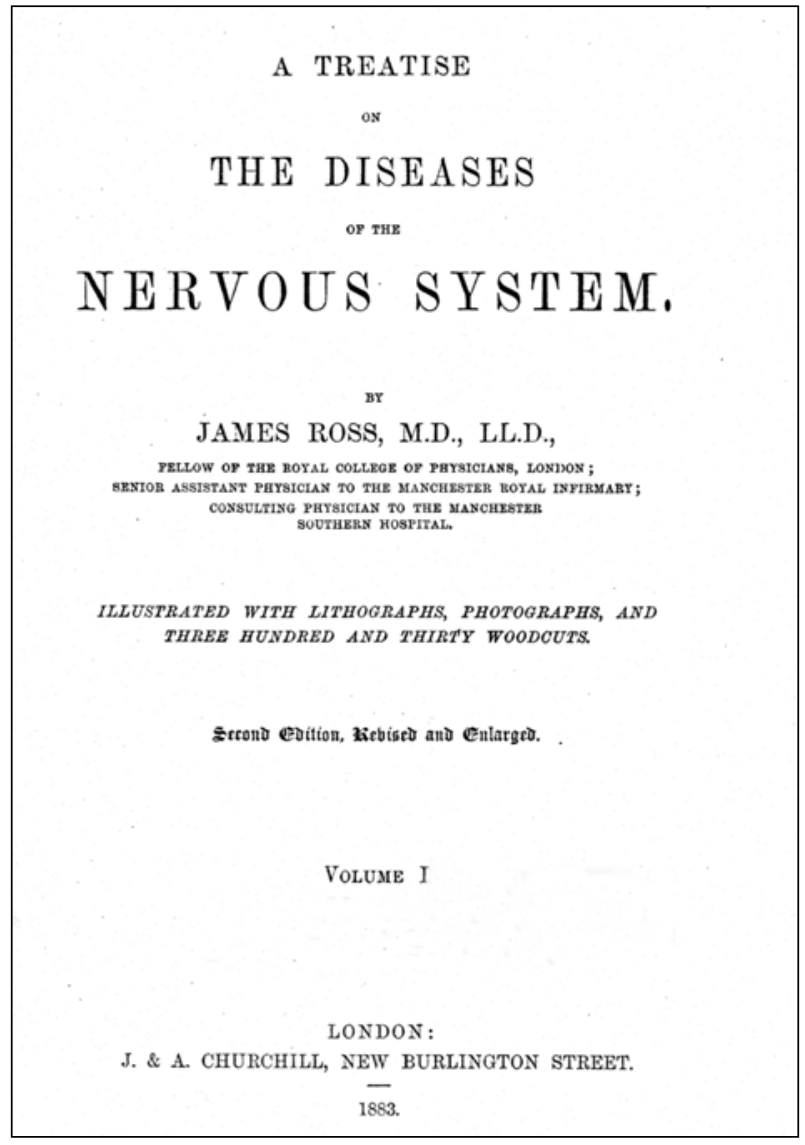

FIGURE 2 Title page of volume one of the second edition of Ross's A Treatise on the Diseases of the Nervous System.

In the 1880s Ross developed an interest in the anatomy and pathology of the peripheral nervous system. He described the distribution of anaesthesia that occurred in disease of the roots and branches of the brachial plexus ${ }^{42}$ and in 1888 , in an important paper describing the segmental distribution of sensory disturbance, he provided an explanation for referred pain in disease of the viscera. ${ }^{43}$ He dealt with the subject of peripheral neuropathy reasonably comprehensively in papers on peripheral neuritis in general ${ }^{44}$ and on the premonitory symptoms of alcoholic paralysis, ${ }^{45}$ which was by then becoming recognised as a peripheral nerve disorder rather than a spinal cord one. His interest in peripheral neuropathy culminated in the posthumous publication of a monograph on the topic, co-authored by Judson Bury. ${ }^{46}$ Ross's own contribution to the work, the first 263 of the book's 424 pages, was written while his health was failing.

Thus in the 1880s Ross made a number of quite significant individual contributions to the literature of developing neurological knowledge, apart from his encyclopaedic account of nervous system disease. However, he did not lay aside entirely his earlier interest in broader biological matters and in philosophical issues. He published small monographs on evolution ${ }^{47}$ and on technical education (copies of the latter have been difficult to trace). In 1890 he ventured into psychiatric 
territory when discussing alcohol-related mental state changes in the context of peripheral neuritis, ${ }^{48}$ and in I89I he published in the journal Brain a paper on the subject of memory, which was more concerned with psychology and philosophy than with neurology itself. ${ }^{49}$

\section{A TREATISE ON THE DISEASES OF THE NERVOUS SYSTEM}

Ross's now largely forgotten Treatise appeared in two volumes in $188 \mathrm{I}$, together amounting to some 1,530 pages of text. In the revised, enlarged and much more extensively referenced second edition of 1883 there were 1,023 pages in volume one and 1,080 pages in volume two, a $30 \%$ expansion of content. Both editions contained numerous illustrations and diagrams of relevant anatomical features. Geoffrey Jefferson ${ }^{13}$ recorded that the publishers had informed him that all I,250 copies of the two editions had been sold.

Because of demand from North America, a considerably shortened handbook version of the second edition appeared in 1885, but it still ran to 723 pages. It was published both in England and in the United States. However, 475 of the 1,000 copies of the Handbook that were printed in England were not sold. Possibly the two editions of the Treatise had saturated the potential market of British physicians and neurologists, and Wilks's very readable, smaller volume of Lectures, ${ }^{4}$ although not illustrated, tended to satisfy any less demanding British readership. Contemporary book reviews indicate that the Treatise was well received and its author's industry and mastery of the literature were praised. The anonymous reviewer of the second edition in The Lancet ${ }^{50}$ pointed out that the book's strength lay in its content of anatomy and physiology, although, like the British Medical Journal's reviewer, ${ }^{51}$ he remarked on its author's propensity to coin long words, such as aesthesioneurosis (for disorder of sensation), even though they were appropriate to their intended purpose. The Lancet reviewer went on:

As a complete effort to deal in a single treatise with the whole of the diseases of the nervous system, this laborious work ranks as the best which has yet appeared in the English tongue..$^{50}$

In the journal Brain, Hughlings Jackson himself reviewed both editions, writing of the first that: "It is too good a work for mere praise' and that 'there is no other work on diseases of the nervous system which covers so much ground, and yet is so harmonious in its several departments as is that of Dr. Ross.'.52

At the time of its appearance, Ross's Treatise had no real English-language competitor. Considered from a presentday standpoint, it was well written and clear, although its language is perhaps not quite as compact as would be expected today and some of the case history material seems unnecessary. In the light of subsequent knowledge some of its anatomical details, particularly with respect to the brain stem, are not entirely correct and quite important disorders such as myasthenia and Huntington's disease are not to be found in the text. Other diagnoses are probably incorrect. In keeping with the fashion of the day the Treatise contains more detail of anatomy and physiology than seems necessary today.

Moreover, Ross, with his highly logical mind, seems to have tried to subdivide his topic entirely on the basis of disorder of particular anatomical regions. Today most neurology books break up the field on a utilitarian mixed basis of anatomy and pathology. Ross dealt with disease of the medulla oblongata and spinal cord as a single category, and disease of the pons and above as a second major category, whereas most subsequent authors have taken the line of division to be at the cervico-medullary junction. Ross's consistently logical approach results in the reader encountering regional manifestations of diseases which involve the central nervous system widely (such as meningitis and multiple sclerosis), before the disease itself has been dealt with as an entity.

Ross attempted to provide an explanation for the basis of every disease manifestation that he described, sometimes predicting (usually accurately) the existence of neural pathways which had not at the time been demonstrated, which perhaps vindicates his anatomical emphasis. Sometimes he seemed to devote disproportionate space to quite rare disorders or collections of neurological manifestations. Reading the book produces an impression that Ross was too dependent on the literature and, whether deliberately or not, had written the text partly to enhance his own understanding and knowledge of neurology. Nevertheless, for someone with less than a half a decade of concentrated neurological experience to have had the courage and industry to undertake so massive a task, and to carry it out so adequately and correctly in the light of contemporary knowledge, the work represents a remarkable achievement.

\section{GOWERS' MANUAL OF DISEASES OF THE NERVOUS SYSTEM}

After the appearance of the first edition of Gowers' Manual, volume one in 1886 and volume two in 1888 , Ross's Treatise seems to have disappeared fairly rapidly from the awareness of the general neurological community. In 1949 Macdonald Critchley, in his biography of Gowers, ${ }^{53}$ did not mention Ross's book when considering the neurology texts with which Gowers' Manual was in competition. The Manual was cheaper (advertised at 12 shillings and 6 pence for volume one and 15 shillings for volume two) and smaller than Ross's Treatise (52 shillings and 6 pence for both volumes). However, because of the way the Manual was printed 
and because of its smaller number of illustrations it probably contains more text. When it appeared it was more up to date at a time when neurological knowledge was advancing quickly, and it dealt with a wider range of disease entities. It was better written than the Treatise, and on reading gave the impression that the author already had an extensive mastery of the topics he dealt with and was writing mainly, if not entirely, for the enlightenment of his readers.

The Manual today produces a stronger impression of being based on carefully documented and critically analysed personal experience rather than on the writings of other people, however assiduously they were assembled and assessed. Gowers had spent at least a decade longer than Ross in studying and managing nervous system disease before his major work appeared, and this greater experience shows.

\section{DISCUSSION}

Over a period of a dozen years James Ross, already middle-aged, made a very significant original contribution to developing neurological knowledge in the Victorian era. He wrote the entire content of a massive and extremely well-documented textbook on the subject, a book that seems to have been regarded as more than adequate by his peers until an even better book became available soon afterwards.

He was unlucky that this happened when it did, and one wonders what the situation might have been had Ross produced a third edition of his Treatise around the time of the appearance of Gowers' second edition. With his intellectual ability and his industry, and with the added neurological experience that he would have accumulated as a busy consultant, Ross might easily have produced a work that would have been a worthy rival for Gowers' Manual. However, Gowers had the advantage that he worked within a group of active professional neurological colleagues in London at Queen Square, whereas Ross worked largely alone in a provincial city, except for his association with the physician and pathologist Julius Dreschfeld. ${ }^{54}$

Had a third edition of Ross's Treatise been written, the situation may have also produced a degree of conflict of commercial interest for the publisher J\&A Churchill, who had brought out the earlier editions of the textbooks of both Ross and Gowers. Unfortunately, the increasing decline in Ross's health over the last two years of his life and his relatively early death left Gowers and his Manual in undisputed possession of the field. As time passed, Ross and his great endeavour became increasingly forgotten, a fate neither he nor his Treatise deserved.

\section{REFERENCES}

I Romberg MH. A manual of the nervous diseases of man. Trans. EH Sieveking. London: New Sydenham Society; 1853.

2 Rosenthal M. A clinical treatise on the diseases of the nervous system. Trans. L Putzel. New York:William Wood \& Co.; 1879.

3 Hammond WA. A treatise on diseases of the nervous system. New York: D Appleton \& Co.; I87I.

4 Wilks S. Lectures on diseases of the nervous system. London: J \& A Churchill; 1878.

5 Reynolds JR, editor. A system of medicine. 2nd ed. Vol. 2. London: Macmillan; 1872.

6 Von Ziemssen $\mathrm{H}$, editor. A cyclopaedia of the practice of medicine. Vol. II-I4. New York:William Wood \& Co; 1876-1878.

7 Charcot JM. Clinical lectures on the diseases of the nervous system. Vols I and 2, trans. G Sigerson. Vol. 3 trans. T Savill. London: New Sydenham Society; 1877, I88I, 1889.

8 Gowers WR. A manual of diseases of the nervous system. London: J\& A Churchill; I886-88. 2nd ed. 1892-93. 3rd ed. 1899.

9 Ross J. A treatise on the diseases of the nervous system. London:J \& A Churchill; 1881. 2nd ed. 1883.

10 Anonymous. Obituary. Professor James Ross, MD, LL.D, FRCP. Lancet 1892; i:612-3.

II Anonymous. James Ross MD FRCP LLD. Br Med J 1892; I:528-9. doi:I0.II36/bmj.I.I627.528-a

12 Moore N. Ross, James ( $837-1892)$. In: Oxford dictionary of national biography. Oxford: Oxford University Press; 2004.

13 Jefferson G. James Ross, Sir William Thorburn, R T Williamson. Pioneers of neurology. In: Jefferson G. Selected papers. Springfield: Charles C Thomas; 1960. p.195-209.

I4 Brockbank W. Professor James Ross (I837-I892). In: Brockbank W, editor. The honorary medical staff of the Manchester Royal Infirmary 1830-1948. Manchester: Manchester University Press; 1965. p. 87-9.

I5 Ross J. On the action of alcohol. Br Med J I873; 2:395-7. doi:I0.II36/bmj.2.666.395

16 Mellor SG. Ross, John (1833-1920). In: Australian dictionary of biography. Vol. 6. Melbourne: Melbourne University Press; 1976. p. 6I-2.

17 Ross J. Inflammation of mucous membrane. $\mathrm{Br}$ Med J I863; 2:33I-2. doi:I0.II36/bmj.2.142.331

I8 Ross J. On counter-irritation: a theory constructed by the deductive method of investigation. London: J Churchill and Sons; 1869.

19 Ross J. The law of parsimony. Br Med J 1869; 2: I32-3. doi: I0.II36/ bmj.2.448.132-a

20 Ross J. Mr. Howorth on Darwinism. Nature I87I; 4:22I-2. doi: I0.1038/00422Id0

2I Ross J.Dr.Bell Pettigrew on vitality. Lancet I873; ii:789. doi:I0.I0I6/ S0I40-6736(02)69237-2

22 Ross J. On protoplasm; being an examination of Dr James Hutchinson Stirling's criticism of Professor Huxley's view. London: Hardwicke; 1874

23 Ross J. The graft theory of disease. London:J \& A Churchill; 1872.

24 Ross J. On the action of mercury. Br Med J I874; 2:287-8.

25 Ross J. Lecture on comparative pharmacology and therapeutics. $\mathrm{Br}$ Med J 1875; I:236-9. doi:I0.I I36/bmj.I.738.236

26 Ross J. Handbook of the diseases of the nervous system. London: ] \& A Churchill; 1885; and Philadelphia: Lea Brothers \& Co.; 1885.

27 Ross J. Distribution of the arteries of the spinal cord. Brain 1880; 2:569-75 and 3:80-4.

28 Ross J. Cases of intracranial tumour. Brain 1880; 3:|2|-4. doi:10.1093/brain/3.I.I2I

29 Jackson JH.A study of convulsions. Trans St Andrews Med Grad Assoc I 870; 3: 162-204. Reprinted in Taylor J, editor. Selected writings of John Hughlings Jackson.Vol I. London: Staples Press; 1958. p. 8-36.

30 Fritsch G, Hitzig E. Über die elektrische Erregbarkeit des Grosshirns. Arch Anat Physiol Wissen 1870; 37:300-32.

31 Ferrier D. The localization of cerebral disease. London: Smith, Elder \& Co.; 1878. 
32 Ross J.A case of multiple tubercular tumours. Brain I885; 7:50I-9. doi:10.1093/brain/7.4.50I

33 Ross J.A case of amnesia aphasia occasioned by a fall on the head. Lancet I88I; ii:904-5. doi:10.1016/S0I40-6736(02)38127-3

34 Ross J. On aphasia: being a contribution to the subject of the dissolution of speech from cerebral disease. London: J \& A Churchill; 1887.

35 Taylor J, editor. Selected writings of John Hughlings Jackson. Vol. 2. London: Staples Press; 1958.

36 Broadbent WH. A case of peculiar affection of speech, with commentary. Brain 1878/I879; I:484-503. doi:10.1093/brain/I.4.484

37 Ross J. Labio-glosso-pharyngeal paralysis of cerebral origin. Brain 1882; 5: 145-69. doi:10.1093/brain/5.2.145

38 Ross J. On a case of pseudo-hypertrophic paralysis. Br Med J 1883 I:200-2. doi: 10.1 136/bmj.I.1153.200

40 Ross J. On the spasmodic paralyses of infancy. Brain 1882; 5:34463, 473-9I. doi: 10.1093/brain/5.3.344

40 Ross $\mathrm{J}$. Notes on the diagnosis of various forms of paralysis of the muscles of external relation. Manchester: Cornish, Ireland \& Co.; 1884.

41 Ross J. On a case of locomotor ataxia with laryngeal crises, and one of primary sclerosis of the columns of Goll, complicated by ophthalmoplegia externa. Brain 1886; 9:24-4I. doi:10.1093/ brain/9.1.24

42 Ross J. Distribution of anaesthesia in cases of disease of the branches and of the roots of the brachial plexus. Brain 1884; 7:5I-76. doi:10.1093/brain/7.1.5I
43 Ross J. On the segmental distribution of sensory disorders. Brain 1888; 10:333-6I. doi: 10.1093/brain/10.4.333

44 Ross J. On peripheral neuritis. Br Med J I887; I:6-9. doi:I0.I I36/ bmj.I.I357.6

45 Ross J. The premonitory symptoms of alcoholic paralysis. Lancet I889; i: I I25-8. doi:I0.1016/S0|40-6736(0I)9/308-X

46 Ross J, Bury JS. On peripheral neuritis. London: Griffin; I 893.

47 Ross J. On evolution. An address delivered at the opening of Owens College Medical School. Manchester: Cornish; 1888

48 Ross J. On the psychical disorders of peripheral neuritis.J Ment Sci 1890; 36:159-72.

49 Ross J. On memory. Brain I89|; |4:35-50. doi:I0.1093/ brain/I4.I.35

50 Anonymous. A treatise on the diseases of the nervous system. Lancet 1884; i: I 18-9.

51 Anonymous. A treatise on the diseases of the nervous system. $\mathrm{Br}$ Med J 1882; 2:94-5. doi:I0.1 I36/bmj.2.55I.94-a

52 Hughlings Jackson J. A treatise on the diseases of the nervous system. Brain 1882, 1885; 4:519-24 and 8:423-5.

53 Critchley M. Sir William Gowers 1845-19/5. A biographical appreciation. London:William Heinemann; 1949.

54 Brockbank W. Professor Julius Dreschfeld (I845-1907). In: The honorary medical staff of the Manchester Royal Infirmary 1830-1948. Manchester: Manchester University Press; 1965. p. 73-6.

\section{UPDATE COURSE ON ELDERLY MEDICINE}

\section{Monday 16 - Friday 20 May 2011}

\section{Course Director: Dr Andrew T Elder, FRCP Edin, Consultant Geriatrician}

This course is primarily designed for non-UK based consultants, specialists and senior trainees in elderly medicine from around the world. It offers a valuable opportunity to discuss clinical issues in elderly care. Places are limited to 60 , so early application is advised. If doctors resident or working in the UK wish to apply, their details will be placed on a waiting list and they will be contacted in early January $201 \mathrm{I}$ to confirm whether or not a place is available.

Each day will focus on a single clinical topic:

- Preventing readmission of elderly people

- First do no harm

Practical psychiatry for geriatricians

- Stroke disease

Mobility and function

\section{COURSE FEES:}

Weekly rate: $€ 720$ (inc.VAT)

Daily rate: $£ 200$ (inc.VAT)

Late registration fee: $£ 50$ if registering after 4 April 2011

For further details please see: http://events.rcpe.ac.uk or contact:

Christina Gray,

Education, Training and

Standards Department,

Royal College of Physicians,

9 Queen Street,

Edinburgh EH2 IJQ, UK

Tel: +44(0) I3। 2473607

Email: c.gray@rcpe.ac.uk 